\title{
Profesionalisme Sebagai Pelayan Masyarakat Melalui Konsistensi Sikap Perilaku dan Penguatan Kompetensi Bidang Tugas Calon Pegawai Aparatur Sipil Negera Peserta pelatihan Dasar Golongan II Provinsi Sumatera Selatan di Kota Palembang
}

\author{
Sugiastuti \\ Widyaiswara Ahli Madya \\ sugiastuti63@gmail.com
}

\begin{abstract}
Abstrak
Melalui konsistensi sikap perilaku dan penguatan kompetensi bidang tugas Calon Pegawai Negeri Sipil, agar dapat menjaga martabat dan kehormatan, memberikan penguatan dalam menjalankan tugas dengan jujur, bertanggung jawab dan berintegritas tinggi, memahami tugas dengan cermat dan disiplin, melaksanakan tugas layanan dengan sikap hormat, sopan dan tanpa tekanan. Konsistensi sikap perilaku dan penguatan kompetensi teknis bidang tugas diukur menggunakan data hasil observasi sikap perilaku selama proses pembelajaran dan data penilaian penguatan bidang tugas dari penilaian atasan langsung selama penerapan nilai-nilai dasar di tempat kerja. Metode analisis menggunakan metode Analisis Manajemen Object. Hasil akhir konsistensi profesionalisme pelayanan kepada masyarakat mendapat nilai rata-rata dari 40 orang peserta 83,043 dengan kriteria dua (2) orang mendapat nilai sangat memuaskan, dan 38 orang mendapat nilai memuaskan. Dimana dari hasil rata-rata sikap perilaku 8,537 dan konsistensi kompetensi teknis bidang tugas mendapatkan penilaian rata-rata 17,390. Hasil pembahasan konsistensi sikap perilaku dan penguatan kompetensi teknis bidang tugas peserta Pelatihan Dasar Calon Pegawai Negeri Sipil (CPNS) Golongan II Angkatan V Kota Palembang, dapat membentuk CPNS profesional yang berkarakter berdasarkan nilainilai dasar dan peran dan kedudukan PNS dalam Negara Kesatuan Republik Indonesia, serta menguasai bidang tugasnya yang menjadi tanggungjawabnya masing-masing, serta mampu melaksanakan tugas dan perannya secara profesional sebagai pelayan masyarakat.
\end{abstract}

Keyword : pendahuluan, metode yang diusulkan, hasil, kesimpulan saran. 


\section{PENDAHULUAN}

Aparatur sipil negara sebagai sosok warga negara Indonesia yang memenuhi syarat tertentu, dan memenuhi syarat untuk menduduki jabatan tertentu di pemerintahan, dengan melaksanakan tugas-tugas tertentu terkait dengan fungsi penugasannya masing-masing. Dalam melaksanakan tugasnya diharuskan memiliki nilai-nilai kejujuran, bertanggungjawab, berintegritas tinggi, cermat dan disiplin, melayani dengan sikap hormat, sopan, dan tanpa tekanan, melaksanakan tugas sesuai dengan ketentuan peraturan perundang-undangan, melaksanakan tugas sesuai dengan perintah atasan atau pejabat yang berwenang sejauh tidak bertentangan dengan ketentuan peraturan perundang-undangan dan etika pemerintahan (MENPAN, 2014). Untuk memenuhi sebagaimana tuntutan tersebut di atas, maka setiap calon ASN harus mengikuti pendidikan dan pelatihan dasar yang diwajibkan agar dapat menjalankan tugas secara profesional. Calon Pegawai Negeri Sipil yang telah ditetapkan wajib dan harus mengikuti Latihan Dasar (LATSAR) Calon Pegawai Negeri Sipil (CPNS) selama masa percobaan untuk diangkat menjadi Pegawai Negeri Sipil (PNS). Adapun pelatihan dilaksanakan melalui pembelajaran dua (2) kurikulum, yaitu: (1) pembentukan karakter PNS empat, terdiri dari empat (4) agenda, yaitu: (a) agenda Sikap Perilaku Bela Negara, (b) agenda Nilai-Nilai Dasar PNS, (c) Kedudukan dan Peran PNS dalam NKRI, (d) agenda Habituasi dan (2) kurikulum penguatan teknis bidang tugas, terdiri dari dua (2), yaitu (a) kompetensi teknis umum / administrasi), (b) kompetensi teknis substantif (LAN RI, 2018) Untuk materi mata pelatihan: agenda sikap perilaku bela negara (wawasan kebangsaan dan nilai-nilai bela negara, analisis isu kontemporer, kesiapsiagaan bela negara), agenda NilaiNilai Dasar PNS (Akuntabilitas, Nasionalisme, Etika Publik, Komitmen mutu, Anti Korupsi), agenda Kedudukan dan Peran PNS Dalam NKRI (Manajemen ASN, Pelayanan Publik, Whole of government, studi lapangan). Pelatihan Dasar dilaksanakan selama 20 hari untuk pembekalan materi dan kebijakan (81 jam pelajaran) dan aktualisasi di tempat kerja selama tiga puluh (30) hari kerja. Adapun tujuan akhirnya dari pelatihan dasar CPNS adalah PNS yang frofesional dan berkarakter sebagai pelayan masyarakat, yang memiliki disiplin, tanggungjawab dalam menyelesaikan tugas, aktif dan kreatif, teguh prinsif dan sopan santun. Namun kenyataannya, konsistensi kode etik dan kode perilaku belum sepenuhnya diimplementasikan oleh ASN. Konsistensi kode etik dan kode perilaku tidak seperti apa yang menjadi tuntutan standar etika dan standar kode etik, dalam peningkatan kualitas diri ASN. Masih banyak ASN yang menyalah gunakan informasi interern negara, tugas, status, kekuasaan, dan jabatannya untuk mendapat atau mencari keuntungan atau manfaat bagi diri sendiri atau orang lain. Tidak memegang teguh nilai dasar ASN dan tidak menjaga reputasi dan integritas ASN. Masih banyak dan tidak sedikit yang tidak melaksanakan ketentuan peraturan perundangan mengenai disiplin pegawai ASN. Tidak memenuhi standar sebagai kode etik dan kode perilaku, dengan mengabaikan menjaga martabat dan kehormatan ASN, serta tidak dapat melaksanakan tugasnya sesuai standar etika dan standar perilaku. 
Bagaimana seseorang CPNS dapat menginternalisasi dan memahami sikap perilaku dalam dirinya dan mengimplementasikan perannya dalam kehidupan organisasi. Guna membangun dan memberikan penguatan dalam implementasi dan konsistensi sikap perilaku dan penguasaan bidang tugasnya masing-masing agar memiliki kemampuan yang memancarkan kewibawaan, kejujuran, memiliki kualitas diri dalam melaksanakan kehidupan, memiliki kemampuan perilaku dalam meminimalisir pelanggaran kode etik dan kode perilaku. Apakah sebagai PNS konsisten dapat menjalankan tugas kedinasan sebagai pelayan masyarakat yang berkualitas, yang dapat menjaga nama baik organisasi, harkat dan martabat diri sebagai ASN. Masalah ini, akan dibatasi pada masalah: "Apakah konsistensi sikap perilaku dan penguatan bidang tugas dapat mendukung kearah profesionalisme CPNS dalam penguatan perannya sebagai pelayan masyarakat"?, sehingga memiliki kualitas diri, memiliki harkat dan martabat diri, dan dapat menjaga nama baik organisasi.

Adapun tujuan penelitian pertama adalah mengetahui Implementasi kode sikap perilaku PNS sebagai konsistensi kualitas diri dalam memiliki harkat dan martabat, serta dapat menjaga nama baik organisasi, melalui penilaian penguatan kode perilaku. Sedangkan tujuan kedua adalah memonitor implementasi kode perilaku ASN dalam pelaksanaan kewajiban sebagai ASN. Sedangkan manfaatnya sebagai berikut: pertama memberikan informasi kepada pihak-pihak yang berkepentingan perihal konsistensi kode perilaku ASN, melalui penilaian kode perilaku ASN, kedua memberikan masukan kepada pejabat struktural level eselon IV dalam suatu organisasi dalam memilih solusi menerapkan asas profesionalisme dalam pelaksanaan tugas dalam menjaga harkat dan martabat, serta menjaga nama baik organisasi.

\section{TINJAUAN PUSTAKA}

Berdasarkan dan sesuai ketentuan umum pada Pasal 1 dikatakan: “ Aparatur Sipil Negara yang selanjutnya disingkat ASN adalah profesi bagi pegawai negeri sipil dan pegawai pemerintah dengan perjanjian kerja yang bekerja pada instansi pemerintah". Pegawai Aparatur Sipil Negara yang selanjutnya disebut Pegawai ASN adalah pegawai negeri sipil dan pegawai pemerintah dengan perjanjian kerja yang diangkat oleh pejabat pembina kepegawaian dan diserahi tugas dalam suatu jabatan pemerintahan atau diserahi tugas negara lainnya dan digaji berdasarkan peraturan perundang-undangan (MENPAN RI, 2014) Dikemukan juga dalam perundangan tersebut Tentang ASN, secara jelas sudah dituangkan perihal tugas-tugas yang menjadi tanggung jawab seorang ASN. Selanjutnya dapat disampaikan sebagai berikut: tugas ASN Pasal 11 Pegawai ASN bertugas untuk: pegawai ASN bertugas untuk melaksanakan kebijakan publik yang dibuat oleh Pejabat Pembina Kepegawaian sesuai dengan ketentuan peraturan perundang-undangan, memberikan pelayanan publik yang profesional dan berkualitas, mempererat persatuan dan kesatuan Negara Kesatuan Republik Indonesia.

Sesuai Pasal 23 kewajiban Pegawai ASN adalah:Setia dan taat pada Pancasila, Undang-Undang Dasar Negara Republik Indonesia Tahun 1945, 
Negara Kesatuan Republik Indonesia, dan pemerintah yang sah, menjaga persatuan dan kesatuan bangsa, melaksanakan kebijakan yang dirumuskan pejabat pemerintah yang berwenang, mentaati ketentuan peraturan perundang-undangan, melaksanakan tugas kedinasan dengan penuh pengabdian, kejujuran, kesadaran, dan tanggung jawab, menunjukkan integritas dan keteladanan dalam sikap, perilaku, ucapan dan tindakan kepada setiap orang, baik di dalam maupun di luar kedinasan, menyimpan rahasia mengemukakan jabatan rahasia dan jabatan hanya sesuai dapat dengan ketentuan peraturan perundang-undangan; dan bersedia ditempatkan di seluruh wilayah Negara Kesatuan Republik Indonesia (MENPAN RI, 2014).

Sesuai ketentuan pasal 63 pada perundangan tentang ASN, dimana CPNS wajib menjalani masa percobaan yang dilaksanakan melalui proses pendidikan dan pelatihan terintegrasi untuk membangun integritas moral, kejujuran, semangat dan motivasi nasionalisme dan kebangsaan, karakter Kepribadian yang unggul dan bertanggungjawab, dan memperkuat professionalisme serta kompetensi bidang (MENPAN, 2014). Standar kode etik dan kode perilaku dimaksud dalam UU ASN, Pasal 3 huruf $b$ yang bertujuan untuk menjaga martabat dan kehormatan ASN. Dan dimaksud pada ayat (1) berisi pengaturan perilaku agar Pegawai ASN, dapat melaksanakan tugasnya sesuai standar etika dan standar perilaku.

Birokrasi dapat menjamin penggunaan kewenangan secara benar dan tidak salah. Administrator dalam membuat keputusan berdasar pertimbangan. Memastikan terlaksananya nilai-nilai utama dari kepercayaan, integritas. Mengetahui dimana kita berada, dimana yang perlu diperbaiki, dan bagaimana kita membawa semua hal itu secara bersama-sama". Fisher berbicara tentang: "Risk, what have you got to lose"? dalam Sayidan, dimana menurutnya, pendekatan nilai-nilai dan akuntabilitas serta etika yang tepat, perlu diterapkan dalam suatu realita agar tidak terjadi kerugian. Anda tidak dapat menghentikan sesuatu yang terjadi, namun Anda dapat mengambil langkah untuk mencegahnya dan membuat rencana untuk menghadapinya (Sayidan, 2000).

Kode etik dan kode perilaku sebagaimana dimaksud dalam Pasal 3 huruf b bertujuan untuk menjaga martabat dan kehormatan ASN. Dalam pelaksanaan tugas dan kewajiban sebagai bagian dari organisasi, perlu adanya standart perilaku yang sesuai dengan tuntutan tugas tersebut, agar dapat dilaksanakan sesuai asas profesionalisme. Standart perilaku, sebagai pedoman dimaksud adalah kode etik dan kode perilaku ASN. Adapun yang dimaksud dengan kode etik dan kode perilaku ASN dapat dikemukakan sebagai berikut: Sesuai pasal 5 Kode etik dan kode perilaku sebagaimana dimaksud dalam Pasal 3 huruf $b$ bertujuan untuk menjaga martabat dan kehormatan ASN. Kode etik dan kode perilaku sebagaimana dimaksud pada ayat (1) berisi pengaturan perilaku agar Pegawai ASN: melaksanakan tugasnya dengan jujur, bertanggung jawab, dan berintegritas tinggi, melaksanakan tugasnya dengan cermat dan disiplin; Melayani dengan sikap hormat, sopan, dan tanpa tekanan, melaksanakan tugasnya sesuai dengan ketentuan peraturan perundang-undangan, melaksanakan tugasnya sesuai dengan perintah atasan atau pejabat yang berwenang sejauh tidak bertentangan dengan ketentuan peraturan perundang-undangan dan etika pemerintahan, menjaga kerahasiaan yang menyangkut kebijakan negara, menggunakan kekayaan dan barang milik negara secara bertanggung jawab, efektif, dan efisien, menjaga agar 
tidak terjadi konflik kepentingan dalam melaksanakan tugasnya, memberikan informasi secara benar dan tidak menyesatkan kepada pihak lain yang memerlukan informasi terkait kepentingan kedinasan, tidak menyalahgunakan informasi intern negara, tugas, status, kekuasaan, dan jabatannya untuk mendapat atau mencari keuntungan atau manfaat bagi diri sendiri atau untuk orang lain, memegang teguh nilai dasar asn dan selalu menjaga reputasi dan integritas ASN, dan melaksanakan ketentuan peraturan perundang-undangan mengenai disiplin pegawai ASN. Kode etik dan kode perilaku sebagaimana dimaksud pada ayat (1) dilaksanakan sesuai dengan ketentuan peraturan perundang-undangan (MENPAN RI, 2014).

\section{METODE}

Adapun metode penelitian sesuai objek penelitian yaitu dengan menggunakan metode Analisis Manajemen Object, dapat diukur kosistensi sikap dan perilaku dan konsistensi penguatan kompetensi bidang apakah telah dilaksanakan sesuai standar nilai-nilai kehidupan dalam organisasi dan tugastugas yang menjadi tanggung jawab personaliti, dalam melaksanakan fungsinya dalam memberikan pelayanan kepada masyarakat, dengan pendekatan deskriptif kualitatif.

Data yang dipergunakan dalam penelitian ini adalah dua data primer (a) data penilaian sikap dan perilaku, yang dalam penelitian ini adalah diperoleh sebagai hasil observasi selama proses pembelajaran oleh pengajar atau fasilitator. Adapun aspek penilaian sikap perilaku meliputi: disiplin, keaktifan, kerapian, kerjasama, perilaku. dengan menggunakan skala likert (skor perolehan 4,3,2,1). Sedangkan prosentasi dan kategori dihitung sesuai rentang nilai dan rubrik, sebagai berikut: rentang nilai 86-100 (bilamana indikator nilai sikap muncul sebanyak 3 kali atau lebih selama proses pembelajaran); rentang nilai 76-85,99 (bilamana indikator nilai sikap muncul sebanyak 2 kali selama proses pembelajaran); rentang nilai 66.00-75,99 (bilamana indikator nilai sikap muncul sebanyak 1 kali selama proses pembelajaran); rentang nilai <65,99 (bilamana indikator nilai sikap tidak pernah muncul sama sekali selama proses pembelajaran) (LPPKS, 2019). Sedangkan (b) data penilaian penguatan kompetensi bidang, yang diperoleh peserta dari hasil pengamatan atasan langsung tempat bekerja masing-masing peserta, selama proses aktualisasi, sesuai instrumen penilaian.

Penelitian ini dilaksanakan pada satu kelas LATSAR Kota Palembang golongan II Angkatan V, yang dilaksanakan dari tanggal 17 Juni s.d. 14 Agustus Tahun 2019. Bertempat di Balai Penerbangan Politeknik Palembang (jumlah peserta 40 orang).

Sebagai variabel independent adalah: (a) konsistensi sikap dan perilaku, sedangkan (b) Penguatan kompetensi bidang, sedangkan sebagai variabel dependent adalah profesionalisme sebagai pelayan masyarakat.

Penelitian ini menggunakan desain observasi kelas pengamatan sikap perilaku selama proses pembelajaran pada kelas pengamatan dan hasil penilaian atasan langsung peserta LATSAR yang diamati. Data (a) dilakukan penilaian 
observasi sikap perilaku berdasar instrumen yang telah ditetapkan berdasarkan populasi satu (1) sampel hasil penilaian dari 40 orang peserta dan hasil penilaian pemgamatan langsung selama proses pembelajaran oleh fasilitator, pengajar ataupun nara sumber masing-masing materi pelajaran selama 20 hari kelas belajar efektif, dengan bantuan instrumen, yang berisi variabel, yaitu: disiplin, keaktifan, kerapian, kerjasama, perilaku) dengan memberikan contrengan sesuai rubrik sebagaimana instrumen dan rubrik pada lampiran 3. Data kedua (b) merupakan data penguatan kompetensi teknis bidang yang dinilai oleh atasan langsung dari 40 orang pesertabawah binaan atau personalia dalam lingkup kerja di organisasi peserta masing-masing. Penilaian kompetensi bidang diperoleh dari pengamatan atasan langsung terkait hasil penyelesaian tugas pokok dan fungsi yang telah dirancang dan disetujui dan telah dilaksanakan selama habituasi (30 hari kerja), dimana penilaiannya berdasarkan intrumen rekapitulasi nilai penguatan kompetensi teknis bidang tugas yang berisi variabel-variabelberikut, yaitu: (standar kompetensi, jenis penguatan kompetensi, tujuan penguatan, strategi dan metode penguatan, matapelatihan, jumlah jp/hari, tempat pelaksanaan) dengan nilai $20 \%$ sebagaimana lampiran 4 .

Analisis kedua data, yaitu data sikap perilaku dan data hasil observasi pengamatan kompetensi teknis bidang tugas, dilakukan dengan menggunakan bantuan program microsoft exel yaitu menggunakan desain eksperimen dua sampel yang berbeda (yang berhubungan). Analisis kedua data hasil observasi sikap perilaku dan penilaian penguatan kompetensi teknis bidang tugas, untuk menunjukkan apakah keduanya mempengaruhi profesionalisme dalam memberikan pelayanan kepada masyarakat.

\section{HASIL DAN PEMBAHASAN}

Banyaknya pelanggaran etika oleh pejabat, dapat di ilustrasikan sebagaimana kasus berikut: "Masih banyaknya sikap arogansi yang ditunjukkan oleh seorang pemimpin di depan banyak orang, membuktikan kegagalan suatu organisasi dan rendahnya kinerja dari sumber daya manusia, selaku pelaksana kegiatan yang selalu berorientasi kepada hasil kerja. Keteladanan para pemimpin dalam menjunjung tinggi etika dan integritas, masih jauh dari harapan, kurangnya pembinaan moral, etika dan integritas dalam sebuah organisasi oleh pemimpinnya, sehingga tidak efektif dan tidak dimulai dari para pemimpinnya. Apabila perilaku pemimpinnya tidak sesuai dengan kode etik dan kode perilaku dan tidak menjadi teladan dalam peraturan-peraturan yang dibuatnya, maka upaya pembinaan moral, etika dan integritas kepada staff atau bawahannya tidak akan berjalan efektif?"., sehingga memiliki kualitas diri, memiliki harkat dan martabat diri, dan dapat menjaga nama baik.

Dari kasus tersebut di atas dapat diidentifikasi pada kondisi saat ini jika kita nilai masih adanya pelanggaran-pelanggaran sebagai berikut: masih banyaknya organisasi yang tidak berkomitmen dengan seluruh ASN tentang kode etik dan kode perilaku; Kurangnya pembinaan dan tidak adanya komitmen berkenlanjutan untuk meluruskan, dengan menguatkan standar etika dan standar kode etik; 
Kurangnya pemberian panisment sebagai sangsi pelanggaran pada kode etik dan kode perilaku; Kurangnya pemberian reward atau penghargaan atas kinerja dan keberhasilan dalam peningkatan kualitas kerja dan karya kerja yang memiliki inovasi; Kurang melaksanakan evaluasi dan pengawasan internal sesuai standar bidang teknis dalam pelaksanaan tugas; Kurangnya Transparansi dan libatkan secara profesional pihak-pihak yang kompeten dan tidak mengatakan hal esensi bahwa katakan: "hak adalah hak dan yang bathil adalah bathil; Adanya agenda terselubung, dan agenda yang tersembunyi, tidak fokus kepada kewajiban terhadap Tuhan, biasa membicarakan kekuarangan/ sisi negatif orang lain.

Dengan menggunakan metode Analisis Manajemen Object, teryata penyebabnya adalah: "Masih banyaknya organisasi yang tidak berkomitmen dengan seluruh PNS, tentang adaptif kode etik dan kode perilaku". Sehingga mengakibatkan: "Tidak konsistenya pelaksanaan kode etik dan kode perilaku". Pentingya etika dalam pengurusan birokrasi adalah birokrasi diandalkan menjadi pelindung dan pengayoman masyarakat bersikap jujur dan adil serta keseluruhan sistemnya diarahkan unt menjamin adanya hal itu. Birokrasi dapat menjamin penggunaan kewenangan secara benar dan tidak salah. Administrator dalam membuat keputusan berdasar pertimbangan. Memastikan terlaksananya nilai-nilai utama dari kepercayaan. Kita tidak dapat menghentikan sesuatu yang terjadi, namun kita dapat mengambil langkah untuk mencegahnya dan membuat rencana untuk menghadapinya.

Sebagaimana telah dituangkan tugas ASN sesuai Undang-Undang ASN Nomor 5 Tahun 2014 tersebut di atas, yang juga menjadi target yang harus menjadi prioritas dalam memberikan pelayanan publik yang profesional dan berkualitas. Dimana dalam tuntutan etika publik harus memiliki kompetensi bidang teknis yang bermaksa harus memiliki pengetahuan tentang hukum, manajemen program, manajemen strategis, manajemen sumber daya. Sesungguhnya jika diinternalisasi dalam diri ASN rasa tanggung jawab, profesional dan berkualitas dapat dipahami untuk diimplementasikan dalam pelaksanaan tugas dan kehidupan guna peningkatan kualitas diri. Untuk menjunjung tinggi nilai-nilai kemanusiaan, ilmu pengetahuan dan teknologi agar seluruh komponen bangsa mampu menjaga harkat dan martabatnya, berpihak kepada kebenaran untuk mencapai kemaslahatan dan kemajuan sesuai dengan nilai-nilai agama dan budaya. Dapat diwujudkan secara peribadi maupun kolektif dalam karsa, cipta dan karya, yang tercermin dalam perilaku kreatif, inovatif, inventif, dan komunikatif dalam pelaksanaan tugas, serta menciptakan iklim kerja yang kondusif dan pengembangan diri dengan ilmu dan teknologi. Dimana ASN dapat menjaga harkat dan martabat diri, serta dapat menjaga nama baik organisasi. Dalam Undang-Undang Nomor 5 Tahun 2014 Tentang Aparatur Sipil Negara, secara jelas sudah dituangkan perihal tugas-tugas yang menjadi tanggung jawab seorang ASN.

Sesuai amanah Undang-Undang Nomor 5 Tahun 2014 Tentang Aparatur Sipil Negara, secara jelas sudah dituangkan perihal kewajiban yang harus dipatuhi seorang ASN. Sesuai Pasal 23 Kewajiban Pegawai ASN harus pedomani sebagai akuntabilitas untuk kepatuhan. Adaptif terkait dengan bagaimana seorang ASN dapat mentaati ketentuan peraturan perundang-undangan. Berupaya dengan standar kompetensi yang dimiliki untuk menunjukkan integritas dan keteladanan 
dalam sikap, perilaku, ucapan dan tindakan kepada setiap orang, baik di dalam maupun di luar kedinasan.

Kode etik dan kode perilaku sebagai standar dalam penilaian kualitas diri ASN, sesungguhnya jika diinternalisasi dan ASN dapat memahami untuk diimplementasikan dalam pelaksanaan tugas dan kewajiban. Kode etik dan kode perilaku sebagai standart perilaku yang sesuai dengan tuntutan tugas tersebut, dapat dilaksanakan sesuai asas profesionalisme. Standart perilaku, sebagai pedoman dimaksud adalah kode etik dan kode perilaku ASN. Kualitas diri dimaksud adalah ASN dapat menjaga harkat dan martabat diri, serta dapat menjaga nama baik organisasi. Kode etik sebagai aturan yang mengatur tingkah laku dalam suatu kelompok khusus. Kode Etik Profesi dimaksudkan untuk mengatur tingkah laku/etika suatu kelompok khusus dalam masyarakat. Kode Etik ASN seharusnya menjadi pedoman dalam berprilaku, pada upaya pelaksanaan tugas, dituntut kejujuan, adanya rasa tanggung jawab. Setiap orang dalam penyelesaian tugas harus memiliki integritas yang tinggi. Melaksanakan ketentuan peraturan perundang-undangan mengenai disiplin pegawai ASN. Memegang teguh nilai dasar ASN dan selalu menjaga reputasi dan integritas ASN. Kode Etik ASN adalah: melaksanakan tugas dengan cermat dan disiplin; melayani dengan hormat, sopan, tanpa tekanan; melaksnakan tugas sesuai peraturan perundangan; melaksanakan tugas sesuai perintah atasan/pejabat, sejauh tidak bertentangan dengan peratuaran dan Etika Pemerintahan;menjaga Kerahasiaan kebijakan Negara; menggunakan kekayaan BMN/D dengan tanggung jawab, efektif dan efisien; menjaga agar tidak terjadi konflik kepentingan; memberikan informasi yang benar dan tidak menyesatkan; tidak menyalahgunakan informasi intern Negara dan tidak menyesatkan; memegang teguh nilai ASN, menjaga refutasi dan Integritas ASN

Berdasarkan hasil observasi penilaian sikap prilaku dari 40 orang peserta LATSAR golongan II angkatan V Kota Palembang Tahun 2019 diperoleh ratarata 8,537, sedangkan penilaian komptensi penguatan teknis bidang tugas 17,39. Sikap perilaku dalam adaptipnya senantiasa berdasarkan nilai-nilai dasar akuntabilitas, nasionalisme, etika publik, komitment mutu dan anti korupsi, dalam memberikan pelayaan kepada masyarakat yang memuat aspek-aspek berikut: memegang nilai-nilai Pancasila, setia kepada Undang-Undang Dasar NKRI; profesional dan tidak memihak, berprinsip pada keahlian, non diskriminatif, menjunjung standar etika luhur, tanggung jawab kepada publik, mampu sebagai pelaksana, melayani secara jujur, tanggap, cepat, tepat, akurat, EFA, EFI, santun, kepemimpinan berkualitas tinggi, menghargai komunikasi, konsultasi, kerjasama , pencapaian hasil dan kinerja pegawai, mendorong kesetaraan, efektifitas sistem pembinaan yang demokratis dalam sistem karir.

Dalam upaya mewujudkan Organisasi yang berkomitmen dengan seluruh ASN tentangpenerapan kode etik dan kode perilaku, baik dalam pelaksanaan tugas, dan mematuhi kewajibannya. Adanya pembinaan berkenlanjutan menjadi komitmen untuk meluruskan, dengan menguatkan standar etika dan standar kode etik. Adanya tindakan tegas atas pelanggaran dengan menjadikan panisment sebagai sangsi pelanggaran pada kode etik dan kode perilaku. Adanya upaya lebih memotivasi untuk aktualisasi diri ASN, melalui pemberian reward atau penghargaan atas kinerja dan keberhasilan dalam peningkatan kualitas kerja dan 
karya kerja yang memiliki inovasi. Lakukan evaluasi senantiasa dan pengawasan internal sesuai standar bidang teknis dalam pelaksanaan tugas. Transparansi dan libatkan secara profesional pihak-pihak yang kompeten dan katakan hag adalah haq yang bathil adalah bathil. Menghindari dan tidak membiasakan untuk transparansi, tidak ada agenda terselubung, tidak ada agenda yang tersembunyi, fokus kepada kewajiban terhadap Tuhan, tidak membicarakan kekuarangan/ sisi negatif orang lain. Memiliki rasa kebersamaan akan mengurangi sejumlah resiko yang dapat mengekspos kita, atau mengurangi dampak yang ditimbulkannya.

Seyogyanya implementasi secara konsisten dapat dilakukan ha-hal sebagai berikut: Kode etik (code of conduct) yang jelas dan singkat; menentukan ekspektasi dalam memilih apa yang 'benar'; Proses agar orang tetap sadar dan ingat akan kode etik tersebut; Diskusi rutin dewan organisasi dan pimpinan, dalam memanajemen implementasi Akuntabilitas dan etika; Update rutin profil risiko dan diskusi rutin seputar implementasi akuntabilitas dan etika dalam hubungannya dengan praktik pelaksanaan tugas dalam organisasi; Control environtment yang independen;

Seseorang memerlukan kerendahan hati untuk bekerja. Awalnya tempat kerja menjadi suatu komunitas, namun kini hal tersebut tidak lagi terjadi. Kesan bahwa kita semua memiliki rasa kebersamaan telah lenyap. Memiliki rasa kebersamaan akan mengurangi sejumlah risiko yang dapat mengekspos kita, atau mengurangi dampak yang ditimbulkannya.

Kita dapat membuat diri kita sendiri tidak berdaya ketika kita memilih untuk tidak tahu. Namun kita dapat memberi harapan pada diri sendiri ketika akan bersikeras untuk mencari tahu sesuatu. Sebagaimana yang dilakukan oleh orang bijak, mulailah dengan pertanyaan sederhana: Apa yang dapat saya ketahui? Haruskah saya tahu? Apa yang saya tidak tahu? Apa yang kurang dari saya?"

\section{V.KESIMPULAN}

Sikap dan perilaku dan kompetensi teknis bidang tugas senantiasa berdasar standar kode etik dan kode sikap perilaku harus mewaspai segala ucapan dan perbuatan dan tetap berpegang teguh kepada hal-hal: mengaktualisasikan nilainilai dasar etika dalam pelaksanaan tugas dan jabatan, melalui aktualisasi dalam diri pada konsistensi perilaku perihal akuntabilitas ASN, komitmen pada memiliki nilai kebangsaan, dan tidak diskriminasi, semangat dan kecintaan pada kemajuan organisasi dan kemajuan bangsa, tugas dengan penuh rasa tanggung jawab. Untuk konsistensi sikap perilau dan peguatan kompeten teknis bidang tugas agar: tidak bekerja berdasarkan rutinitas, selalu berinovasi, bekerja secara efektif dan efisien dalam penyelenggaraan pemerintahan, menjauhi larangan untuk anti korupsi, berlaku bersih, mencegah dan menghentikan tindakan melanggar, memegang teguh dan menjadikan standar etika dan standar perilaku sebagai pedoman perilaku yang dijunjung tinggi.

Adapun saran yang dapat dipenuhi adalah sebagai pengalaman pencegahan dan konsistensi kode etik dan kode perilaku, yaitu: organisasi mengkomitmenkan dengan seluruh ASN tentang kode etik dan kode perilaku, pembinaan berkenlanjutan menjadi komitmen untuk meluruskan, dengan menguatkan standar 
etika dan standar kode etik (memberikan panisment sebagai sangsi pelanggaran pada kode etik dan kode perilaku, pemberian reward atau penghargaan atas kinerja dan keberhasilan dalam peningkatan kualitas kerja dan karya kerja yang memiliki inovasi, lakukan evaluasi senantiasa dan pengawasan internal sesuai standar bidang teknis dalam pelaksanaan tugas, transparansi dan libatkan secara profesional pihak-pihak yang kompeten dan yang katakan hag adalah haq yang bathil adalah bathil, biasakan tidak ada agenda terselubung, tidak ada agenda yang tersembunyi, fokus kepada kewajiban terhadap Tuhan, tidak membicarakan kekuarangan/ sisi negatif orang lain, memiliki rasa kebersamaan akan mengurangi sejumlah risiko yang dapat mengekspos kita, atau mengurangi dampak yang ditimbulkannya).

\section{DAFTAR PUSTAKA}

LAN RI. (2018). PERKALAN NOMOR 12 TAHUN 2018. JAKARTA: LAN RI.

LPPKS. (2019, Februari Selasa). Instrumen Supervisi dan observasi (materi penguatan kepala sekolah). Instrumen Supervisi dan observasi (materi penguatan kepala sekolah). Bandung, Bandung, Bandung: LPPKS.

MENPAN. (2014). UNDANG-UNDANG ASN NOMOR 5 TAHUN 2014. UNDANGUNDANG ASN NOMOR 5 TAHUN 2014. JAKARTA.

Said, M. (2012). Introspeksi integritas pemerintah . Jakarta: Jawa Pos.

Sayidan, G. (2000). Manajemen Sumber Daya Manusia jilid 2. Jakarta: PT Gunung Agung. 